\title{
PENGARUH ENVIRONMENTAL PERFORMANCE, ENVIRONMENTAL DISCLOSURE, DAN ISO 14001 TERHADAP FINANCIAL PERFORMANCE
}

\author{
Rizky Aulia* and Sofyan Hadinata" \\ *Universitas Islam Negeri Sunan Kalijaga \\ Shariah Accounting Study Program \\ Jalan Marsda Adisucipto, Yogyakarta 55281, Indonesia \\ E-mail: rizkyauliabatubara@gmail.com \\ "Universitas Islam Negeri Sunan Kalijaga \\ Shariah Accounting Study Program \\ Jalan Marsda Adisucipto, Yogyakarta 55281, Indonesia \\ E-mail: sofyan.hadinata@uin-suka.ac.id
}

\begin{abstract}
Abstrak
Penelitian ini bertujuan untuk menguji secara empiris pengaruh environmental performance, environmental disclosure, dan ISO 14001 terhadap financial performance dengan firm size sebagai variabel kontrol. Objek penelitian ini adalah perusahaan dari industri pertambangan dan manufaktur yang masuk pada Indeks Saham Syariah Indonesia (ISSI) dari tahun 2013 sampai 2017. Enviromental performance pada penelitian ini diukur menggunakan PROPER dari Kementerian Lingkungan Hidup dan Kehutanan. Enviromental disclosure diukur menggunakan Indonesian Enviromental Report (IER) indeks dari penelitian Suhardjanto, Tower, dan Brown (2008). ISO 14001 diukur menggunakan variabel dummy, sedangkan financial performance diukur menggunakan Return on Assets (ROA). Desain penelitian adalah penelitian kuantitatif dengan teknik pengambilan sampel menggunakan metode purposive sampling. Metode analisis yang digunakan adalah analisis regresi data panel menggunakan Eviews 10. Hasil penelitian ini menunjukkan bahwa secara statistik enviromental performance dan enviromental disclosure berpengaruh positif terhadap financial performance, sedangkan ISO 14001 tidak berpengaruh terhadap financial performance.
\end{abstract}

Kata kunci: financial performance, environmental performance, environmental disclosure, ISO 14001, Indeks Saham Syariah Indonesia, firm size.

\footnotetext{
Abstract

This study aims to empirically examine the effect of environmental performance, environmental disclosure, and ISO 14001 on financial performance with firm size as a control variable. The object of this study is companies from the mining and manufacturing industries that are included in the Indonesian Sharia Stock Index (ISSI) from 2013 to 2017. Environmental performance in this study was measured using PROPER from the Ministry of Environment and Forestry. Environmental disclosure is measured using the Indonesian Environmental Report (IER) index from Suhardjanto, Tower, and Brown (2008). ISO 14001 is measured using dummy variables, while financial performance is measured using Return on Assets (ROA). The research design is quantitative research with sampling techniques using purposive sampling method. The analytical method used is panel data regression analysis using Eviews 10. The results of this study indicate that statistically environmental performance and environmental disclosure have a positive effect on financial performance, while ISO 14001 has no effect on financial performance.
} 
Keywords: financial performance, environmental performance, environmental disclosure, ISO 14001, Indonesian Shariah Stock Index, firm size

\section{Pendahuluan}

Isu lingkungan yang disebabkan oleh perusahaan bukan suatu hal yang baru. Permasalahan lingkungan yang diakibatkan industri terus menjadi perhatian bersama dan para pelaku bisnis dituntut oleh pihak luar perusahaan untuk selalu menjaga, mengelola, dan melestarikan lingkungan (Putra dan Utami, 2017). Perusahaan menjadi salah satu pihak yang berkontribusi terhadap kerusakan lingkungan, karena kegiatan operasionalnya tidak memperhatikan lingkungan sekitar dan lebih memfokuskan pada keuntungan keuangan semata.

Aktivitas operasional perusahaan bisa menyebabkan beberapa dampak negatif seperti masalah polusi yang banyak dihadapi oleh masyarakat, yaitu: 1) polusi udara, 2) polusi air, dan 3) pembuangan sampah (Irawan dan Swastha, 1981). Perusahaan tidak memperhatikan bagaimana mengolah limbah dengan baik agar tidak mencemari lingkungan sekitar. Dikarenakan perusahaan berada pada lingkungan masyarakat, sudah semestinya perusahaan bertanggung jawab atas segala kegiatan yang berdampak kepada masyarakat, sosial, serta lingkungan (Gozali et al., 2002).

Berbagai Cara telah dilakukan untuk mengurangi dampak kerusakan lingkungan salah satunya dengan mengeluarkan peraturan atau regulasi yang sifatnya nasional dan internasional. Di dalam lingkup nasional salah satu cara mengurangi dampak kerusakan lingkungan yaitu dengan program PROPER yang diterapkan Kementerian Lingkungan Hidup dan Kehutanan. Upaya pada tingkat internasional untuk mengatasi masalah lingkungan salah satunya diterapkan oleh International Organization for Standardization (ISO) dengan cara mengeluarkan ISO 14001 mengenai standar sistem pengelolaan lingkungan. Akan tetapi kedua peraturan ini masih belum mampu menyelesaikan isu lingkungan karena tidak semua perusahaan menerapkan ISO 14001. Sertifikasi ISO 14001 hanya bersifat sukarela, serta membutuhkan biaya yang relatif besar. Biaya audit rutin dan biaya investasi merupakan contoh biaya yang mempengaruhi besar kecilnya biaya yang dikeluarkan untuk ISO 14001 (Aprilasani dkk., 2017).

Kesadaran masyarakat terus meningkat seiring timbulnya dampak negatif dari kegiatan perusahaan (Yendrawati dan Tarusnawati, 2013). Masyarakat meminta kepada pelaku bisnis untuk selalu melaporkan kinerja lingkungannya (Burgwal dan Vieira, 2014). Tuntutan secara formal di Indonesia sudah dituangkan di dalam Undang-Undang Nomor 40 tahun 2007 pasal 66 ayat 6 , menyebutkan bahwa salah satu komponen annual report yang diterbitkan perusahaan yaitu laporan pemenuhan tanggung jawab lingkungan dan sosial.

Entitas bisnis harus membayar lebih sebagai bentuk ganti rugi dan denda akibat kerusakan lingkungan yang ditimbulkan (Ikhsan, 2008). Selain itu, perusahaan dimungkinkan akan kehilangan legitimasi dan kepercayaan di mata masyarakat sehingga berdampak pada keberlangsungan usaha perusahaan yang dapat dilihat dari kinerja keuangannya. Besaran pengembalian (return) tahunan merupakan salah satu indikator penilaian dari financial performance atau kinerja keuangan perusahaan (Almilia, 2008).

Penelitian terkait hubungan environmental performance dengan financial (economic) performance sudah dilakukan secara luas dan hasil yang dilaporkan beragam. Al Tuwaijri et al. (2004), Arafat et al. (2012), Titisari dan Alviana (2012), serta Kabir dan Thai (2017) memperoleh bukti empiris environmental performance berhubungan positif dengan return on asset (ROA). Hasil yang berbeda diperoleh Sparta dan Ayu (2016) menemukan hasil adanya hubungan negatif antara environmental performance dengan profitabilitas. Rockness et al. (1986), Freedman dan Jaggi (1992), Sarumpaet (2005), Rakhiemah dan Agustia (2009), serta Anindito dan Ardiyanto (2012) gagal mendapatkan bukti adanya hubungan kinerja lingkungan dengan kinerja keuangan. Lebih lanjut, Elsayed dan Paton (2005) menemukan beberapa bukti yang berbeda pengaruh enviromental performance lintas industri untuk satu pengukuran kinerja keuangan (ROA), enviromental performance berpengaruh positif terhadap ROA untuk industri kimia dan telekomunikasi, tapi berdampak negatif untuk perusahaan tekstil, pakaian, besi, dan kendaraan bermotor.

Adapun mengenai environmental disclosure, penelitian Razeed (2010) membuktikan terdapat hubungan positif antara enviromental disclosure menggunakan pelaporan hard copy dengan kinerja keuangan. Sementara itu penelitian lain, Rohmah dan Wahyudin (2015) memperoleh bukti empiris enviromental disclosure memiliki pengaruh positif terhadap kinerja ekonomi yang diukur dengan ROA. Sementara itu, hasil penelitian yang mencatat environmental disclosure tidak mempengaruhi kinerja keuangan dilakukan oleh Freedman dan 
Jaggi (1982), Rakhiemah dan Agustina (2007), Sutami dkk. (2011), Nor et al. (2016), serta Sparta dan Ayu (2016).

Penelitian mengenai ISO 14001 terhadap ROA dilakukan oleh Ong et al., (2016). Ong et al. (2016) memperoleh bukti ISO 14001 memiliki pengaruh positif terhadap ROA. Hasil penelitian lainnya oleh Sueb dan Keraf (2012), membuktikan bahwa dengan penerapan ISO 14001 dapat menjadi stimulus dalam peningkatan kinerja keuangan. Sedangkan, Lindrianasari (2007) dan Heras-Saizarbitoria et al. (2011) tidak menemukan bukti empiris bahwa ISO 14001 memiliki pengaruh pada financial performance.

Melihat hasil dari beberapa temuan sebelumnya yang belum konsisten, menjadi justifikasi untuk peneliti melakukan penelitian ini. Selain dari ketidakkonsistensian hasil tersebut, penelitian ini memfokuskan pada objek penelitian yaitu perusahaan pertambangan dan manufaktur yang terindeks pada ISSI. Menurut Burgwal dan Vieira (2014), perusahaan pertambangan dan manufaktur dikategorikan sebagai high profile company dan dalam menjalankan operasionalnya selalu berinteraksi langsung dengan alam atau lingkungan. High profile industry secara umum mempunyai ciri seperti jumlah karyawan yang banyak dan proses produksinya menghasilkan residu, seperti limbah dan polusi (Zuhroh dan Sukmawati, 2003). Roberts (1992) menyebutkan bahwa high profile industry memiliki daya tarik paling intuitif sebagai industri dengan visibilitas konsumen, tingkat risiko politik yang tinggi, dan persaingan yang ketat dan terkonsentrasi.

\section{Kajian Teori}

\section{Legitimacy Theory}

Teori legitimasi mengemukakan bahwa perusahaan bisa mempengaruhi serta dipengaruhi masyarakat pada tempat perusahaan tersebut melakukan aktivitas operasionalnya (Mahrani dan Soewarno, 2018). Untuk mendapatkan legitimasi, organisasi harus beroperasi pada norma dan harapan masyarakat, serta organisasi perlu melakukan pengungkapan sukarela sebagai bentuk pertanggungjawaban kepada publik atau pemangku kepentingan (Dowling dan Pfeffer, 1975, dan Deegan, 2002). Masyarakat sudah memiliki kesadaran terhadap dampak lingkungan yang dilakukan oleh perusahaan sehingga terdapat konsekuensi apabila manajemen gagal melegitimasi kegiataan yaitu intervensi dari pemerintah yang merupakan badan terpilih untuk memperhatikan masalah masyarakat (Wilmhurst dan Frost, 2000).
Financial performance dapat mencerminkan prestasi perusahaan, sehingga bisa digunakan sebagai ukuran untuk menilai baik buruknya keuangan suatu entitas bisnis pada periode tertentu (Wulandari dan Hidayah, 2013). Financial performance dapat dianalis melalui rasio keuangan yang ada pada laporan keuangan (Mahrani dan Soewarno, 2018). Menurut teori legitimasi, perusahaan seharusnya menjalankan operasi bisnisnya dengan mempertimbangkan masyarakat di sekitarnya sebagai upaya untuk menjamin kelangsungan operasional perusahaan (Burgwal dan Vieira, 2014). Perusahaan diharapkan tidak hanya mengedepankan laba, tetapi juga harus memikirkan aspek sosial (people) serta lingkungan (planet).

\section{Environmental Performance}

Menurut Sambharakrehsna (2009) dan Widodo (2017) environmental performance merupakan suatu hasil yang terukur dari sistem pengelolaan lingkungan. Prayanthi dan Mandagi (2015) mengemukakan bahwa manajemen lingkungan merupakan suatu strategi perusahaan yang akan menggambarkan kinerja lingkungan berdasarkan suatu standar evaluasi tertentu. Lebih lanjut, dikatakan bahwa strategi pengelolaan lingkungan akan menghasilkan enviromental performance yang baik dan akan berdampak pada peningkatan financial performance (Klassen dan McLauglin, 1996).

Kementerian Lingkungan Hidup dan Kehutanan telah menerapkan PROPER untuk meningkatkan keikutsertaan perusahaan terhadap pengelolaan lingkungan. PROPER didesain menggunakan instrumen insentif dan disinsentif. Instrumen insentif berupa penyebarluasan informasi kepada masyarakat untuk perusahaan yang berkinerja baik atas pengelolaan lingkungan. Kinerja tersebut ditandai menggunakan label biru, hijau, dan emas. Adapun sebaliknya (diinsentif), penyampaikan informasi dengan label merah dan hitam menandakan kinerja pengelolaan lingkungan tidak baik (menlhk.go.id, 2019).

\section{Environmental Disclosure}

Putra dan Utami (2017) mendefinisikan environmental disclosure sebagai bentuk pengungkapan lingkungan yang sifatnya kualitatif maupun kuantitatif oleh suatu perusahaan secara sukarela. Pengungkapan tersebut bermanfaat sebagai media untuk pengambilan keputusan mengenai ekonomi, sosial, maupun politis (Suhardjanto dan Miranti, 2009). Selain itu bisa dikatakan bahwa pengungkapan tersebut merupakan kewajiban perusahaan kepada masyarakat akibat dampak dari aktivitas operasional perusahaan pada lingkungan sekitarnya. Walaupun perusahaan memiliki

\section{Financial Performance}


kewajiban untuk mengeluarkan biaya lebih terkait environmental disclosure (Suhardjanto dan Miranti, 2009) namun manfaat dari pengungkapan lingkungan akan dirasakan oleh perusahaan untuk jangka panjang.

Bentuk responsibilitas, akuntabilitas, dan transparansi terhadap stakeholders-nya diungkapkan dalam annual report maupun laporan terpisah lainnya mengenai informasi ekonomi, lingkungan hidup, dan sosial (Machmud dan Djakman, 2008). Adanya laporan itu memiliki tujuan untuk menjalin komunikasi perusahaan yang meyakinkan para pemangku kepentingan mengenai fokus perusahaan terhadap tanggungjawab sosial dan lingkungan mereka yang terintegrasi dengan setiap aspek kegiatan operasionalnya (Tilt, 1997 dan Darwin, 2007).

\section{ISO 14001}

ISO 14001 adalah standar yang berlaku secara internasional yang menyediakaan alat praktik bagi perusahaan maupun organisasi mengenai pengelolaan tanggung jawab lingkungan mereka (iso.org). Standar interasional ISO 14001 ini dibuat pada tahun 1996 yang bertujuan agar perusahaan menginformasikan tentang penerapan Environmental Management System (ESM) atau Sistem Manajemen Lingkungan (SML) (Francia and Ayerbe, 2009). International Organization for Standardization (2015) mengemukakan bahwa terdapat keuntungan dari SML ISO 14001 yaitu: (a) memberikan bukti perusahaan patuh terhadap regulasi, (b) menumbuhkan peran serta pimpinan dan karyawan, (c) meningkatkan kepercayaan diri stakeholders dan juga reputasi organisasi, (d) mewujudkan tujuan bisnis strategis melalui integrasi pengelolaan lingkungan dengan pengelolaan bisnis, (e) menciptakan keunggulan kompetitif dan keuangan melalui pengurangan biaya, dan (f) selalu berupaya meningkatkan kinerja lingkungan bersama vendor dengan cara memasukkan mereka ke dalam sistem bisnis.

\section{Konsep Triple Bottom Line}

Di Indonesia terdapat banyak perusahaan yang masih memikirkan dan mementingkan profit atau keuntungan (Heikal, 2013). Konsep triple bottom line menganjurkan perusahaan untuk memperhatikan tiga pilar yaitu laba (profit), lingkungan (planet), dan orang (people). Ketika entitas bisnis (perusahaan) hanya berfokus pada keuntungan semata maka perusahaan akan melakukan segala cara untuk memaksimalkannya, tanpa memperhatikan kerusakan yang diakibatkan oleh kegiatan perusahaan tersebut seperti contohnya pencemaran lingkungan maupun kesehatan masyarakat di sekitar perusahaan beroperasi.

\section{Pengembangan Hipotesis} Environmental performance terhadap financial
performance

Teori legitimasi menyebutkan bahwa masyarakat sudah memiliki kesadaran terhadap dampak lingkungan yang diakibatkan oleh operasi perusahaan, sehingga menimbulkan konsekuensi apabila manajemen gagal melegitimasi kegiatan mereka (Wilmhurst dan Frost, 2000). Saat suatu perusahaan melakukan kinerja lingkungan maka tersebut menandakan bahwa perusahaan memberikan perhatian dan tanggung jawab terhadap dampak lingkungan yang disebabkan perusahaan dan hal ini akan menarik perhatian masyarakat ataupun konsumen untuk membeli barang dari perusahaan tersebut sebagai bentuk apresiasi telah melakukan kinerja lingkungan (Fitriani, 2013).

Kabir dan Thai (2017) memaparkan bahwa tanggungjawab lingkungan oleh perusahaan bisa menimbulkan biaya serta manfaat tambahan yang kemudian dapat berdampak terhadap kinerja keuangan. Biaya tersebut terkait dengan kepatuhan, pengelolaan limbah, pengendalian polusi, serta tanggung jawab di masa depan (Kabir dan Thai, 2017). Manfaat dapat berupa peningkatan pendapatan dari kontribusi pada sumber daya perusahaan yang kemudian membawa keunggulan kompetitif dan meningkatkan citra perusahaan (Russo dan Fouts, 1997).

Penelitian terdahulu mendokumentasikan bahwa environmental performance berhubungan dengan economic performance (Al Tuwaijri et al., 2004). Ada bukti empiris lainnya yang lebih eksplisit, menemukan bukti kinerja lingkungan dapat meningkatkan financial performance (Djuitaningsih dan Ristiawati, 2011, Arafat et al., 2012, Titisari dan Alviana, 2012, Fitriani, 2013, serta Kabir dan Thai, 2017). Berdasarkan pemaparan di atas, maka diusulkan:

Hipotesis 1: Environmental performance berpengaruh positif terhadap financial performance

Environmental disclosure terhadap financial performance

Burgwal dan Vieira (2014) menyampaikan bahwa di dalam teori legitimasi, adanya reaksi atau tekanan dari masyarakat kepada perusahaan mendorong adanya pengungkapan (disclosure) yang dilakukan manajemen perusahaan atas kegiatan lingkungan mereka. Dapat diperoleh nilai tambah (added value) dari para pemangku kepentingan (stakeholders) bagi perusahaan atas pengungkapan lingkungan (enviromental disclosure) tersebut yang tersaji pada annual report perusahaan. Hal tersebut kemudian meningkatkan kepercayaan stakeholder karena 
mereka lebih menyukai perusahaan yang ramah lingkungan (Ong et al., 2016) sehingga dalam jangka waktu tertentu dapat meningkatkan Return on Asset (ROA).

Al Tuwaijri et al. (2004), Lindrianasari (2007), Wulandari dan Hidayah (2013), Rohmah dan Wahyudin (2015), Nurleli dan Faisal (2016), dan Rizkan dkk. (2017) memperoleh hasil ada hubungan positif antara environmental disclosure dengan kinerja keuangan. Penelitian lain oleh Rohmah dan Wahyudin (2015) mendapatkan hasil bahwa environmental disclosure dapat meningkatkan kinerja ekonomi. Berdasarkan pada pemaparan sebelumnya, maka dapat dibuat:

Hipotesis 2: Environmental disclosure pengaruh positif terhadap financial performance

\section{ISO 14001 terhadap financial performance}

Dalam teori legitimasi dinyatakan bahwa perusahaan seharusnya menjalan aktivitas perusahaannya sesuai atau sejalan dengan norma yang terdapat di masyarakat. Untuk mewujudkan hal tersebut ISO 14001 mendukung konsep Triple Bottom Line yang menjelaskan bahwa perusahaan wajib memiliki rasa kepedulian atau tanggung jawab terhadap lingkungan (planet). Perusahaan dapat menerapkan hal tersebut melalui sertifikasi ISO 14001, sehingga dapat meningkatkan kepercayaan dari stakeholder.

Penelitian empiris sebelumnya oleh Saizarbitoria et al. (2010), Sueb dan Keraf (2012), dan Ong et al. (2016) memperoleh hasil ISO 14001 meningkatkan kinerja keuangan. Berdasarkan pada pemaparan sebelumnya, maka dapat dibuat:

Hipotesis 3: ISO 14001 memiliki pengaruh positif terhadap financial performance.

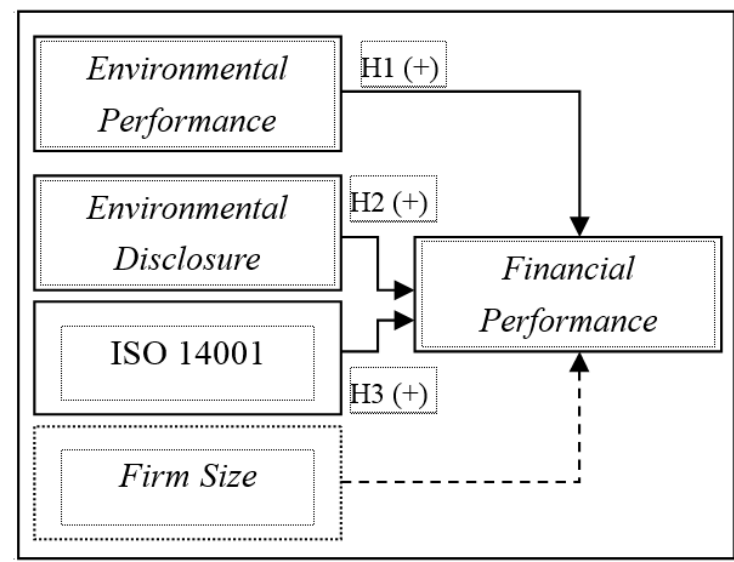

Gambar 1. Kerangka Pemikiran

\section{Metode Penelitian}

Jenis penelitian ini adalah kuantitatif. Data yang digunakan merupakan data panel, yaitu gabungan antara data seksi silang (beberapa variabel) dengan data runtut waktu (Winarno, 2015). Data penelitian ini didapat dari annual report masing-masing perusahaan, diakses melalui website Bursa Efek Indondesia. Sumber data mengenai PROPER diperoleh melalui database Kementerian Lingkungan Hidup dan Kehutanan. Sampel penelitian ini diperoleh melalui teknik pengambilan sampel dengan kriteria tertentu atau sering disebut dengan purposive sampling (Sekaran dan Bougie, 2010).

Adapun kriteria untuk pengambilan sampel yaitu: (a) perusahaan pertambangan dan manufaktur yang masuk ISSI dari 2013 sampai dengan 2017, (b) mempublikasikan laporan tahunan 2013-2017 secara lengkap, (c) menjadi peserta PROPER tahun 2013-2017 secara berturut-turut, (d) peserta PROPER yang melaporkan pengungkapan lingkungan (environmental disclosure) pada laporan tahunan pada periode 2013-2017. Penggunaan industri manufaktur dan pertambangan sebagai bentuk cerminan high profile industry sangat sesuai dalam konteks Indonesia. High profile industry secara umum mempunyai ciri seperti jumlah karyawan yang banyak dan proses produksinya menghasilkan residu, seperti limbah dan polusi (Zuhroh dan Sukmawati, 2003). Roberts (1992) juga menyampaikan bahwa high profile industry memiliki daya tarik paling intuitif sebagai industri dengan visibilitas konsumen, tingkat risiko politik yang tinggi, dan persaingan yang ketat dan terkonsentrasi.

\section{Definisi Operasional}

\section{Financial Performance}

Financial performance dapat mencerminkan kondisi dan prestasi suatu perusahaan sehingga mampu menilai baik buruknya keuangan perusahaan (Wulandari dan Hidayah, 2013). Penelitian ini menggunakan ROA sebagai proksi financial performance, karena ROA menggambarkan kemampuan perusahaan dalam menghasilkan laba yang berasal dari pengelolaan sumber daya (aset) perusahaan secara keseluruhan atau bisa dikatakan sebagai salah satu teknik pengukuran yang komprehensif dibandingkan pengukuran yang lain. ROA dalam penelitian ini diukur dengan formula:

$\mathrm{ROA}=\frac{\text { Earning before income tax }}{\text { Total Assets }} \times 100 \%$

\section{Environmental Performance}

Menurut Sambharakrehsna (2009) dan Widodo (2017) enviromental performance adalah suatu hasil yang terukur dari sistem pengelolaan lingkungan. 
Environmental performance mengukur seberapa besar perhatian perusahaan untuk ikut andil dalam pelestarian lingkungan dalam bentuk tingkatan atau peringkat yang dikeluarkan oleh Kementerian Lingkungan Hidup dan Kehutanan yaitu PROPER. Penelitian ini menggunakan PROPER sebagai alat ukur environmental performance. Penilaian PROPER terdiri dari 5 warna yaitu emas, hijau, biru, merah, hitam yang menunjukkan baik buruknya kinerja lingkungan perusahaan.

\section{Environmental Disclosure}

Menurut Putra dan Utami (2017) environmental disclosure dilakukam oleh suatu perusahaan secara sukarela yang bentuk pengungkapan lingkungan bisa bersifat kualitatif maupun kuantitatif. Environmental disclosure penelitian ini diukur menggunakan Indonesian Environmental Reporting Index yang mengadopsi penelitian Suhardjanto et al. (2008), yang mana indeksnya sudah disesuaikan dengan tuntutan stakeholder di Indonesia agar hasil yang diperoleh lebih akurat.

\section{ISO 14001}

Pengukuran ISO 14001 pada penelitian ini merujuk pada penelitian Sueb dan Keraf (2014). Dengan menggunakan dummy variable, dimana angka 1 diberikan bagi perusahaan yang sudah mendapat sertifikasi ISO 14001, sedangkan angka 0 bagi perusahaan yang belum memiliki sertifikasi ISO 14001.

\section{Variabel Kontrol}

Firm size digunakan sebagai variabel kontrol penelitian ini, karena besar kecilnya perusahaan dimungkinkan mempengaruhi kinerja keuangan perusahaan. Penelitian Darmawan dan Sukartha (2014) digunakan sebagai rujukan untuk mengukur firm size, dengan rumus:

$$
\text { Size }=\text { Ln Total Assets }
$$

\section{Hasil dan Pembahasan}

Terdapat 117 perusahaan pada industri pertambangan dan manufaktur yang terindeks ISSI secara terus menerus dari tahun 2013 sampai 2017. Perusahaan yang tidak terdaftar sebagai peserta PROPER sejumlah 23 untuk perusahaan pertambangan dan 68 untuk perusahaan manufaktur. Berdasarkan angka tersebut, maka didapat ada 26 perusahaan yang memenuhi kriteria untuk dijadikan sampel. Dengan periode waktu selama 5 tahun, maka jumlah data penelitian ini adalah 130 .

\section{Statistik Deskriptif}

Disajikannya statistik deskriptif dapat dijadikan gambaran umum atau informasi awal mengenai data yang bisa dilihat dari rerata (mean), nilai tengah (median), modus, dan standard deviation. Hasil statistik deskriptif ditampilkan dalam tabel berikut:

TABEL 1

HASIL STATISTIK DESKRIPTIF

\begin{tabular}{|l|c|c|c|c|c|}
\hline & ROA & PROPER & IER & ISO & SIZE \\
\hline Mean & 0,19097 & 3,15385 & 12,6486 & 0,55385 & 19,2438 \\
\hline Med. & 0,09703 & 3,00000 & 12,4000 & 1,00000 & 17,1785 \\
\hline Max. & 6,07957 & 5,00000 & 31,7600 & 1,00000 & 30,4414 \\
\hline Min. & $-0,05497$ & 2,00000 & 3,05000 & 0,00000 & 5,08293 \\
\hline Std Dev. & 0,55266 & 0,76210 & 7,02401 & 0,49902 & 7,16264 \\
\hline Obs. & 130 & 130 & 130 & 130 & 130 \\
\hline
\end{tabular}

memiliki ROA terbesar dari tahun 2013 sampai dengan 2017 sebesar 6,079565, sedangkan nilai terkecilnya adalah 0,054972. Return on Assets terbesar diperoleh PT. Aneka Tambang (ANTM) di tahun 2013. Sementara itu, ROA terkecil juga didapat PT. Aneka Tambang (ANTM) pada tahun 2015.

\section{b. Environmental Performance (PROPER)}

Dari hasil statistik deskriptif tersebut, terlihat bahwa perusahaan yang memperoleh peringkat 5 diwakili oleh warna emas selama tahun 2013-2017 sebanyak 5 perusahaan di antaranya 2 perusahaan manufaktur dan 3 perusahaan pertambangan. Perusahaan yang memperoleh peringkat 2 diwakili oleh warna merah selama tahun 2013-2017 sebanyak 14 perusahaan terdiri dari perusahaan manufaktur. Dari hasil tersebut menunjukkan masih banyak perusahaan yang memperoleh peringkat merah yang bisa dikatakan perusahaan-perusahaan tersebut kurang melakukan kinerja lingkungan.

c. Environmental Disclosure (IER)

Melihat hasil dari tabel 1 menunjukkan bahwa perusahaan pada pertambangan dan manufaktur yang masuk ISSI selama tahun 2013-2017 memiliki indeks tertinggi sejumlah 31,76 dan terendah sejumlah 3,05. Bobot indeks tertinggi sejumlah 31, 76 dimiliki oleh PT Indocement Tunggal Prakarsa (INTP) berturut-turut selama tahun 2013-2014. Adapun bobot indeks terendah sejumlah 3,05 dimiliki oleh PT Prasidha Aneka Niaga (PSDN) berturut-turut selama tahun 2013-2014.

\section{d. ISO 14001}

Berdasarkan tabel 1, ada sebanyak 15 perusahaan yang memiliki sertifikasi ISO 14001 di tahun 2013, 13 perusahaan pada tahun 2014, tahun 2015 ada 15 perusahaan, tahun 2016 tercatat 14 perusahaan, sedangkan untuk tahun 2017 tercatat 14 perusahaan.

\section{Pengujian Pemilihan Model}




\section{Uji Chow}

Uji chow dilakukan untuk menentukan model regresi terbaik antara fixed effect atau common effect. Hasil dari uji chow ditampilkan pada tabel berikut:

TABEL 2

UJICHOW

Test cross-section fixed effects

\begin{tabular}{|l|r|r|c|}
\hline Effects Test & Statistic & d.f. & Prob. \\
\hline Cross-section F & 1.480703 & $(25,100)$ & 0.0892 \\
\hline Cross-section Chi-square & 40.942071 & 25 & 0.0233 \\
\hline
\end{tabular}

Diperoleh hasil Prob. Cross-section Chi Square sebesar 0, 0233, yang memiliki arti bahwa nilai tersebut $<0$, 05, sehingga $\mathrm{H}_{1}$ diterima atau $\mathrm{H}_{0}$ ditolak. Dari hasil tersebut, maka fixed effect merupakan model terpilih. Setelah mendapatkan model fixed effect lebih baik dari common effect, langkah berikutnya yang harus dilakukan yaitu uji hausman.

\section{Uji Hausman}

Uji ini bertujuan untuk menetapkan model yang terbaik antara random dengan fixed effect. Hasil uji hausman disajikan pada tabel 3 .

TABEL 3

UJI HAUSMAN

\begin{tabular}{|l|r|c|c|}
\hline Test Summary & Chi-Sq. Statistic & Chi-Sq. d.f. & Prob. \\
\hline $\begin{array}{l}\text { Cross-section } \\
\text { random }\end{array}$ & 12,231385 & 4 & 0,0157 \\
\hline
\end{tabular}

Berdasarkan tabel 3 besarnya probabilitas sebesar 0,0157 atau $<0,05$, maka dapat diartikan $\mathrm{H}_{1}$ diterima dan $\mathrm{H}_{0}$ ditolak. Hasil tersebut memperlihatkan bahwa model fixed effect merupakan model yang dipilih. Setelah melakukan uji chow dan uji hausman, maka terpilih fixed effect sebagai model yang terbaik dibanding random effect dan common effect.

\section{Uji Asumsi Klasik}

\section{Uji Multikolinearitas}

Hasil uji multikolinearitas penelitian ini ditampilkan pada tabel 4 .

TABEL 4

UJI MULTIKOLINEARITAS

\begin{tabular}{|l|c|c|c|c|}
\hline & PROPER & IER & ISO & SIZE \\
\hline PROPER & 1,000000 & & & \\
\hline IER & 0,033165 & 1,000000 & & \\
\hline ISO & 0,065746 & 0,200359 & 1,000000 & \\
\hline LN SIZE & $-0,077622$ & $-0,006289$ & $-0,184092$ & 1,000000 \\
\hline
\end{tabular}

Berdasarkan angka-angka pada tabel 4, dapat disimpulkan bahwa tidak terjadi multikolinearitas. Hal tersebut bisa dilihat dari hubungan antarvariabel independen (selain dengan variabel yang sama) yang nilainya lebih kecil dari 0,80 .

\section{Uji Heteroskedastisitas}

Hasil tabel 5 memperlihatkan bahwa p-value Chi-Square(4) untuk Obs*R-R-squared sebesar 0,1139 atau $>0,05$, maka dapat dikatakan tidak terjadi adanya masalah heteroskedastisitas.

TABEL 5

UJI HETEROSKEDASTISITAS

\begin{tabular}{|l|l|l|l|}
\hline F-statistic & 1.900005 & Prob. F(4,125) & 0.1145 \\
\hline Obs*R-R-squared & 7.450999 & Prob. Chi-Square(4) & 0.1139 \\
\hline Scaled explained SS & 305.9412 & Prob. Chi-Square(4) & 0.0000 \\
\hline
\end{tabular}

\section{Estimasi Model Regresi}

\section{Uji F untuk Signifikansi Model}

TABEL 6

HASIL UJI F

\begin{tabular}{|l|l|l|l|}
\hline R-squared & 0,322560 & $\begin{array}{l}\text { Mean dependent } \\
\text { var }\end{array}$ & 0,190973 \\
\hline $\begin{array}{l}\text { Adjusted } \\
\text { R-Squared }\end{array}$ & 0,126102 & $\begin{array}{l}\text { S.D. dependent } \\
\text { var }\end{array}$ & 0,552664 \\
\hline $\begin{array}{l}\text { S.E. of } \\
\text { regression }\end{array}$ & 0,516645 & $\begin{array}{l}\text { Akaike info } \\
\text { criterion }\end{array}$ & 1,716251 \\
\hline $\begin{array}{l}\text { Sum squared } \\
\text { resid }\end{array}$ & 26,69216 & $\begin{array}{l}\text { Schwarz } \\
\text { criterion }\end{array}$ & 2,377990 \\
\hline $\begin{array}{l}\text { Log } \\
\text { likelehood }\end{array}$ & $-81,55630$ & $\begin{array}{l}\text { Hannan-Quinn } \\
\text { criter. }\end{array}$ & 1,985137 \\
\hline F-statistic & 1,641879 & $\begin{array}{l}\text { Durbin-Watson } \\
\text { stat }\end{array}$ & 1,293047 \\
\hline $\begin{array}{c}\text { Prob } \\
\text { (F-statistic) }\end{array}$ & 0,037426 & \\
\hline
\end{tabular}

Hasil pengujian tabel 6 memperlihatkan angka probabilitas (F-statistik) sebesar 0,037426. Nilai signifikansi 0,037426 atau <0, 05, dapat dikatakan bahwa ada pengaruh secara serentak variabel independen terhadap dependen.

\section{Uji Hipotesis}

Hasil regresi ditampilkan pada tabel berikut:

$$
\text { TABEL } 7
$$

HASIL UJI T

\begin{tabular}{|c|c|c|c|c|}
\hline Variable & Coefficient & Std. Error & t-Statistic & Prob. \\
\hline C & $-4,469029$ & 1,208436 & $-3,698192$ & 0,0004 \\
\hline PROPER & 0,343675 & 0,093353 & 3,681440 & $0,0004^{*}$ \\
\hline IER & 0,018272 & 0,009014 & 2,027198 & $0,0453^{*}$ \\
\hline ISO & 0,315380 & 0,164708 & 1,914781 & 0,0584 \\
\hline LN SIZE & 0,167639 & 0,054745 & 3,062155 & 0,0028 \\
\hline
\end{tabular}

Dari tabel 7, menunjukkan variabel enviromental performance (PROPER), environmental disclosure (IER), dan ukuran perusahaan (LN_Size) berpengaruh positif terhadap financial performance 
(return on assets).

\section{Koefisien Determinasi (Adjusted R-square)}

TABEL 8

KOEFISIEN DETERMINASI

\begin{tabular}{|l|c|}
\hline R-squared & 0,322560 \\
\hline Adjusted R-squared & 0,126102 \\
\hline
\end{tabular}

Berdasarkan tabel 8, nilai Adjusted R-square sebesar 0,126102 . Hasil itu memperlihatkan persentase sumbangan variabel independen (enviromental performance, enviromental disclosure, ISO 14001, dan LN_Size) mampu menjelaskan variabel dependen (ROA) sebesar 12, 6\%. Adapun sisanya, $87,4 \%$ dipengaruhi oleh variabel lainnya yang tidak digunakan dalam model regresi penelitian ini.

\section{Pembahasan}

1. Pengaruh Environmental Performance terhadap Financial Performance

Di dalam tabel 7 memperlihatkan nilai koefisien variabel environmental performance (PROPER) sebesar 0,343675 dengan nilai probabilitas 0,0004 atau $<0,05$. Dari angka tersebut, bisa disimpulkan bahawa environmental performance (PROPER) berpengaruh positif terhadap financial performance (ROA), sehingga $\mathrm{H}_{1}$ pada penelitian ini didukung. Dari hal tersebut bisa dikatakan bahwa dengan meningkatnya enviromental performance perusahaan dapat menyebabkan naiknya financial performance perusahaan.

Dari hasil tersebut bisa dikatakan sesuai dengan teori legitimasi yang menyebutkan bahwa masyarakat dinilai telah memiliki kesadaran terhadap dampak lingkungan yang dilakukan oleh perusahaan sehingga terdapat konsekuensi apabila manajemen gagal melegitimasi kegiatan (Wilmhurst dan Frost, 2000). Enviromental performance berpengaruh positif terhadap financial performance, bisa diartikan perusahaan yang memiliki environmental performance yang tinggi dapat menimbulkan respon atau penilaian yang baik dari stakeholder-nya sehingga dapat meningkatkan pendapatan perusahaan (Fitriani, 2013).

Hasil empiris penelitian ini konsisten dengan hasil penelitian Al Tuwaijri et al. (2004), Djuitaningsih dan Ristiawati (2011), Arafat et al. (2012), Titisari dan Alviana (2012), Fitriani (2013), serta Kabir dan Thai (2017). Sementara, Sarumpaet (2005), Rakhiemah dan Agustia (2009), Sutami dkk. (2011), dan Wulandari dan Hidayah (2013) menemukan hasil yang berbeda dengan penelitian ini. Selain itu, hasil penelitian lainnya oleh Putra dan Utami (2017) mendapatkan bukti bahwa enviromental performance berpengaruh negatif terhadap economic performance yang diukur dengan ROA.

2. Pengaruh Environmental Disclosure terhadap Financial Performance

Pengujian $\mathrm{H}_{2}$ dapat ditunjukkan di dalam tabel 7 yang memperlihatkan bahwa koefisien variabel environmental disclosure sebesar 0,018272 dengan nilai probabilitas 0,0453. Dari angka tersebut, diartikan bahwa environmental disclosure berpengaruh positif terhadap financial performance (ROA). Oleh karena itu, $\mathrm{H}_{2}$ diterima. Dari hasil tersebut bisa dikatakan apabila enviromental disclosure naik, maka menyebabkan kenaikan pada return on asset.

Dalam teori legitimasi disebutkan bahwa perusahaan melakukan pengungkapan (disclosure) informasi lingkungan sebagai reaksi atas tekanan masyarakat (Burgwal dan Vieira, 2014). Hasil dari penelitian ini selaras dengan Al Tuwaijri et al. (2004), Wulandari dan Hidayah (2013), Rohmah dan Wahyudin (2015), serta Rizkan dkk (2017). Namun berkebalikan dengan yang diperoleh Rakhiemah dan Agustina (2007), Rahman dkk. (2009), Sutami dkk. (2011), dan Sparta dan Ayu (2016).

\section{Pengaruh ISO 14001 terhadap Financial Performance}

Dilihat dari hasil Uji T pada tabel 7 menunjukkan angka koefisien ISO 14001 sebesar 0,315380 dengan nilai probabilitas 0,0584 atau $>0,05$. Angka tersebut memperlihatkan bahwa ISO 14001 tidak mempengaruhi financial performance (ROA). Oleh karena itu, $\mathrm{H}_{0}$ diterima atau $\mathrm{H}_{3}$ dalam penelitian ini ditolak. Hasil tersebut bisa diartikan bahwa perusahaan yang kepemilikan ISO 14001 atau tidak memiliki ISO 14001 tidak bisa memprediksi financial performance.

Hasil dari penelitian ini berbeda dengan penelitian sebelumnya yang dilakukan oleh Saizarbitoria et al. (2010), Sueb dan Keraf (2012), serta Ong et al. (2016) yang mendapatkan hasil empiris sertifikat ISO 14001 berpengaruh terhadap financial performance. Hasil penelitian ini tidak sesuai dengan teori legitimasi yang menyebutkan bahwa keadaan masyarakat sekitar sangat peka terhadap lingkungan (Putra dan Utami, 2017). Publik menilai bahwa ISO 14001 belum memberikan manfaat ekonomi bagi perusahaan karena ISO 14001 hanya merupakan bentuk kepedulian terhadap lingkungan. Selain itu, ISO 14001 juga merupakan sistem manajemen yang mahal (Ong et al., 2016).

Selain itu, hasil penelitian ini berbeda kemungkinan dikarenakan ISO 14001 belum begitu dikenal oleh stakeholders dan waktu yang dibutuhkan lama untuk mendapatkan pengaruh ISO 14001 terhadap financial performance, sebab sistem ISO 14001 
adalah salah satu sistem ISO yang sulit dioptimalkan dibanding sistem ISO lainnya (Aprilasani dkk., 2017). Namun, penelitian ini mendapatkan hasil yang sama dengan hasil penelitian Lindrianasari (2007), Titisari dan Alviana (2012), dan Hazudin et al. (2015).

\section{Simpulan dan Saran}

\section{Simpulan}

Dari analisis data diperoleh hasil bahwa environmental performance (PROPER) dan environmental disclosure (indeks IER) memiliki pengaruh positif terhadap return on asset sebagai pengukur dari financial performance. Hal itu sejalan dengan teori legitimasi, ketika perusahaan memperhatikan masalah lingkungan dan tidak mengejar keuntungan semata maka perusahaan akan memperoleh kepercayaan dari pemangku kepentingan, sehingga mendukung keberlangsungan operasional perusahaan dalam bentuk peningkatan financial performance (ROA), sedangkan variabel ISO 14001 tidak berpengaruh terhadap financial performance (ROA). ISO 14001 tidak berdampak pada peningkatan ROA kemungkinan karena para pemangku kepentingan belum familiar dengan ISO 14001, selain itu waktu yang dibutuhkan cukup lama atau jangka panjang untuk melihat dampaknya pada kinerja keuangan.

\section{Saran}

Implikasi hasil penelitian ini bagi pemerintah sebagai pihak pembuat regulasi tentunya tidak hanya membuat regulasi terkait dengan tanggungjawab sosial dan lingkungan, tetapi yang lebih penting yaitu pengawasan dan penilaian atas pelaksanaan tanggung jawab perusahaan terhadap lingkungan sekitar. Lebih konkrit lagi pemerintah dapat memberikan punishment yang berat bagi perusahaan yang terbukti merusak atau mencermari lingkungan, atau sebaliknya memberikan reward bagi perusahaan yang berperan aktif dalam menjaga lingkungan. Adapun bagi perusahaan tidak hanya mengejar laba semata, tetapi harus memperhatikan lingkungan sekitar guna mendapat legitimasi dari pemangku kepentingan untuk menunjang operasi perusahaan, sehingga keberlanjutan operasional perusahaan dapat terjamin. Bagi masyarakat, sebagai pihak berpotensi yang paling terdampak dari operasional perusahaan sebelum perusahaan berdiri harus dilakukan kajian bersama dan kontrak, selama berjalannya operasi harus selalu ikut serta dalam mengawasi jalannya operasi perusahaan, apabila perusahaan terindikasi merusak lingkungan tentunya bisa melapor kepada pihak yang berwenang. Bagi investor saat ini dan potensial, tanggungjawab sosial dan lingkungan perusahaan berdampak pada kinerja keuangan perusahaan sehingga tidak perlu muncul rasa khawatir atas return investasi dan keberlangsungan perusahaan.

Untuk penelitian berikutnya disarankan memperluas objek penelitian, dengan menambahkan industri yang masuk kategori high profile company dimana aktivitas bisnisnya bersinggungan langsung dengan masyarakat. Penelitian berikutnya dapat memasukkan variabel lain yang belum digunakan pada penelitian ini seperti biaya lingkungan dan struktur kepemilikan. Selain itu, penelitian lebih lanjut dapat menggunakan GRI G4 sebagai pengukur variabel environmental disclosure, dan dapat mengembangkan model penelitian dengan menggunakan harga saham sebagai variabel dependen.

\section{Daftar Pustaka}

Al Tuwaijri, S. A., T. E. Christensen, \& K.E. Hughes II. 2004. The Relation among Environmental Disclosure, Environmental Performance, and Economic Performance: a Simultaneous Equations Approach, Accounting, Organizations, and Society, Vol. 29, Issues 5-6, pp. 447-471.

Almilia, L. S. 2008. Faktor-faktor yang Mempengaruhi Pengungkapan Sukarela Internet Financial and Sustainability Reporting. JAAI, Vol. 12, No. 2, hal. 117-131,

Anindito, T. \& M. D. Ardiyanto. 2012. Pengaruh Kinerja Lingkungan terhadap Corporate Social Responsibility (CSR) Disclosure dan Kinerja Finansial Perusahaan Kimia dan Pertambangan yang Terdaftar di Bursa Efek Indonesia. Diponegoro Journal of Accounting, Vol. 2, No. 1, hal. 1-12.

Aprilasani, Z., C. A. A. Said, T. E. B. Soesilo, \& A. I. Munandar. 2017. Pengaruh Sertifikasi Sistem Manajemen Lingkungan ISO 14001 Pada Kinerja Perusahaan. MIX: Jurnal Ilmiah Manajemen, VII (2), hal. 316-329.

Arafat, M. Y., A. Warokka, \& S. R. Dewi. 2012. Does Environmental Performance Really Matter? A Lesson from the Debate of Environmental Disclosure and Firm Performance. Journal of Organizational Management Studies, pp. $1-15$.

Bragdon, J, \& Marlin, J. 1972. Is pollution profitable? Risk Management, 19 (4), pp. 9-18.

Burgwal, D. \& R. J. O. Vieira. 2014. Environmental Disclosure Determinants in Dutch Listed Companies. R. Cont Fin-USP, 
Sao Paulo, Vol. 25, No. 64, pp. 60-78,

Darmawan, I G. H. \& I M. Sukartha. 2014. Pengaruh Penerapan Corporate Govarnance, Leverage, Return on Assets, dan Ukuran Perusahaan pada Penghindaran Pajak. Ejurnal Akuntansi Universitas Udayana, Vol 9, No. 1, hal. 143-161.

Darwin, A. (2007). Pentingnya Laporan Keberlanjutan, Akuntansi Indonesia, Vol. 3, 12-14.

Deegan, C. 2002. Introduction: The Legitimising Effect of Social and Enviromental Disclosures - A Theoretical Foundation. Accounting, Auditing \& Accountability Journal, Vol. 15, No. 3, pp. 282-311.

Djuitaningsih, T. \& E. E. Ristiawati. 2011. Pengaruh Kinerja Lingkungan dan Kepemilikan Asing terhadap Kinerja Finansial Perusahaan. Jurnal Akuntansi Universitas Jember, Vol 9, No. 2, hal. 31-54.

Dowling, J. \& J. Pfeffer. 1975. Organisational Legitimacy: Social Values and Organisational Behavior. Pacific Sociological Review, Vol. 18 Issue 1, pp. 122-136.

Elsayed, K. \& D. Paton. 2004. The Impact of Environmental Performance on Firm Performance: Static and Dynamic Panel Data Evidence. Structural Change and Economic Dynamics, Vol. 16, Issue 3, pp. 395-412.

Freedman, M. \& B. Jaggi. 1992. An Investigation of the Long-Run Relationship Between Pollution Performance and Economic Performance: the Case of Pulp-and-Paper Firms. Critical Perspectives on Accounting, 3(4), pp. 315-336.

Fitriani, A. 2013. Pengaruh Kinerja Lingkungan dan Biaya Lingkungan terhadap Kinerja Keuangan Pada BUMN. Jurnal Ilmu Manajemen, Vol. 1, No. 1, hal. 137-148.

Francia, J. C. \& C. Garces-Ayerbe. 2009. ISO 140001 Environmental Certification: A Sign Valued by the Market. Environ Resource Econ, Vol. 44, Issue 2, pp. 245-262.

Gozali, O N., J. C.Y. How \& P. Verhoeven. 2002. The Economic Consequence of Voluntary Environmental Information Disclosure. International Congress on Environmental Modelling and Software, pp. $484-489$

Hazudin, S. F., S. A. Mohamad, I. Azer, R. Daud, \& H. Paino. 2015. ISO 14001 and Financial Performance: Is the Accreditation Financially Worth It for Malaysian Firms. Procedia Economics and Finance, Vol. 31, pp. 56-61.

Heikal. 2013. Hubungan Antara Kinerja Lingkungan dan Kinerja Keuangan Perusahaan. Jakarta: Universitas Trisakti.

Heras-Saizarbitoria, I., J. F. Molina-Azorín, dan G. P. Dick. 2011. ISO 14001 Certification and Financial Performance: Selection-effect versus Treatment-effect. Journal of Cleaner Production, Vol. 19, No. 1, pp. $1-12$.

Ikhsan, A. 2008. Akuntansi Lingkungan dan Pengungkapannya. Yogyakarta: Graha Ilmu.

Irawan \& B. Swastha. 1981. Lingkungan Perusahaan. Yogyakarta: BPFE-UGM Yogyakarta.

Iso.org/iso-14001-enviromental-management.html (diakses 12 Oktober 2019).

Internastional Organization for Standardization. 2015. ISO 14001 Key Benefits. Switzerland

Kabir, R. \& H. M. Thai. 2017. Does Corporate Shape The Relationship Between Corporate Social Responsibility and Financial Performance. Pasific Accounting Review, Vol. 29, No. 2, pp. 227-258.

Klassen, R. \& C. McLaughlin. 1996. The Impact of Environmental Management on Firm Performance. Management Science, Vol 42, No. 1, pp. 1199-1214.

Lindrianasari. 2007. Hubungan Antara Kinerja Lingkungan dan Kualitas Pengungkapan Lingkungan dengan Kinerja Ekonomi Perusahaan di Indonesia. JAAI, Vol. 11, No. 2, hal. 159-172.

Machmud, N. \& C. D. Djakman. (2008). Pengaruh Struktur Kepemilikian Terhadap Luas Pengungkapan Tanggung Jawab Sosial (CSR Disclosure) pada Laporan Tahunan Perusahaan: Studi Empiris pada Perusahaan Go Publik yang Tercatat di Bursa Efek Indonesia Tahun 2006. Simposium Nasional XI. Pontianak.

Mahrani, M. \& N. Soewarno. 2018. The Effect of Good Corporate Governance Mechanism and Corporate Social Responsibility on Financial Performance with Earnings Management as Mediating Variable. Asian Journal of Accounting Research, Vol 3, No. 1, pp. 41-60.

Menlhk.go.id/site/post/119 diakses 14 Oktober 2019.

Nor, N. Md, N. A. S. Bahari, N. A. Adnan, S. M. Q. A. S. Kamal, \& I. M. Ali. 2016. The Effect of Environmental Disclosure on Financial Performance in Malaysia. 
Procedia Economics and Finance, Vol. 35, pp. 117-126.

Nurleli \& Faisal. 2016. Pengaruh Pengungkapan Informasi Lingkungan Terhadap Kinerja Keuangan. Kajian Akuntansi, Vol. 17, No. 2, hal. 31-54.

O’Donovan, G. 2002. Environmental Disclosures in the Annual Report: Extending the Applicability and Predictive Power of Legitimacy Theory. Accounting, Auditing, \& Accountability Journal, 15(3), pp. 344-371.

Ong, T. S., B. H. Teh, S. H. Ng, \& W. N. Soh. 2016. Environmental Management System and Financial Performance. Institutions and Economics, Vol. 8, No. 2, pp. 26-52.

Prayanthi, I. \& D. Mandagi. 2015. The Impact of Environmental Performance as Realization of Environmental Regulation on Financial Performance. The International Journal of Accounting and Business Society, Vol. 23, No. 2, pp.1-16.

Putra, D. \& I. L. Utami. 2017. Pengaruh Environmental Performance terhadap Environmental Disclosure dan Economic Performance. Jurnal Akuntansi, Vol. 9, No. 1, hal. 1-11.

Rahman, S. A. b. A., R. b. Yusoff, \& W. N. b. W. Mohamed. 2010. Environmental Disclosure and Financial Performance: An empirical study of Malaysia, Thailand and Singapore. Social and Environmental Accountability Journal, Vol. 29, No. 2, pp. 46-58.

Rakhiemah, A. N. \& D. Agustia. 2009. Pengaruh Kinerja Lingkungan terhadap Corporate Social Responsibility (CSR) Disclosure dan Kinerja Finansial Perusahaan Manufaktur yang Terdaftar di Bursa Efek Indonesia. Prosiding Simposium Nasional Akuntansi XII, hal. 1-31.

Razeed, A. 2010. Determinants of Environmental Disclosure Practice of US Resource Companies: Hard Copy Versus Internet. A Paper Presented at Australian CSEAR, Sydney, pp.1-23.

Rizkan, M., Islahuddin, \& Nadirsyah. 2017. Pengaruh Environmental Performance dan Environmental Disclosure Terhadap Financial Performance Perusahaan Pertambangan dan Pemegang HPH/HPHTI yang Terdaftar di Bursa Efek Indonesia. Jurnal Megister Akuntasi Pascasarjana Universitas
Syiah Kuala, Vol. 6, No. 3, hal. 35-42.

Roberts, R. W. 1992. Determinants of Corporate Social Responsibility Disclosure: An Application of Stakeholder Theory. Accounting, Organizations and Society, Vol. 17, No. 6, pp. 595-612.

Rockness, J., P. Schlachter, \& H. Rockness. 1986. Hazardous Waste Disposal, Corporate Disclosure and Financial Performance in the Chemical Industry. Advances in Public Interest Accounting, 1, 167-191.

Rohmah, I. L. \& A. Wahyudin. 2015. Pengaruh Environmental Performance terhadap Economic Performance dengan Environmental Disclosure sebagai Variabel Intevening. Accounting Analysis Journal, Vol. 4, No. 1, hal. 113.

Russo, M. V. \& P. A. Fouts. 1997. A Resource-Based Perspective on Corporate Environmental Performance and Profitability. Academy of Management Journal, Vol 40, pp. 534-559.

Saizarbitoria, I. H., J. F. Molina-Azorin, \& G. P. M. Dick. 2010. ISO 14001 Certification and Financial Performance: Selection-effect versus Treatment-effect. Journal of Clearner Production, Vol. 19, Issue 1, pp. 1-12.

Sambharakreshna, Y. 2009. Akuntansi Lingkungan dan Akuntansi Manajemen Lingkungan: Suatu Komponen Dasar Strategi Bisnis. Jurnal Infestasi, Vol. 5, No. 1, hal. 1-21.

Sarumpaet, S. 2005. The Relationship Between Environmental Performance and Financial Performance of Indonesian Companies. Jurnal Akuntansi dan Keuangan, Vol. 7, No. 2, hal. 89-98.

Sekaran, U. \& R. Bougie. 2010. Research Methods for Business: A Skill Building Approach. Fifth Edition. UK: John Wiley \& Sons Ltd.

Sparta \& D. Ayu. 2016. Dampak Eviromental Performance dan Enviromental Disclosure Terhadap Profitabilitas Perusahaan. Jurnal Keuangan dan Perbankan, Vol. 13, No. 1, hal. 35-54.

Sueb, M. \& M. N. I. Keraf. 2012. Relasi Sistem Manajemen Lingkungan ISO 14001 dan Kinerja Keuangan. Jurnal Dinamika Manajemen, Vol. 3, No. 1, hal. 69-75.

Suhardjanto, D., G. Tower, \& A. Brown. 2008. Indonesian Stakeholders' Perceptions on Environmental Information. Journal of the Asia-Pacific Centre for Environmental Accountability, Vol. 14, No. 4, hal. 2-11.

Suhardjanto, D. \& L. Miranti. 2009. Indonesian Environmental Reporting Index dan 
Karakteristik Perusahaan. Jurnal Akuntansi dan Auditing Indonesia, Vol 13, No. 1, hal. 1-17.

Sutami, E., R. Anggaraini ZR, \& A. Zakaria. 2011. The Effect of Voluntary Disclosure of Environmental Performance and Level of Externalities to Corporate Economic Performance (A Case Study in Companies Listed in Indonesia Stock Exchange). The $3^{\text {rd }}$ International Conference on Humanities and Social Science Proceedings, hal. 1-10.

Titisari, K. H. \& K. Alviana. 2012. Pengaruh Environmental Performance terhadap Economic Performance. Jurnal Akuntansi dan Keuangan Indonesia, Vol. 9, No. 1, hal. 56-67.

Tilt, C. A. 1997. Environmental Policies of Major Companies: Australian Evidence. British Accounting Review, Vol. 29, pp. 367-94.

Widodo, H. 2017. Economic Performance and Factors Affecting The Context Socio Economic Environmental Accounting (SEEA). Advances in Social Science, Education and Humanities Research (ASSEHR), Vol. 125.1st International Conference on Intellectuals Global Responsibility (ICIGR), hal. 10-14.

Wilmshurst, T. D \& G. R. Frost. 2000. Corporate Environmental Reporting A Test of Legitimacy Theory. Accounting, Auditing \& Accountability Journal, Vol. 13, No.1, pp. 10-26.

Winarno, W. W. 2015. Analisis Ekonometrika dan Statistika dengan Eviews Edisi 4. Yogyakarta: UPP STIM YKPN.

Wulandari, R. D. \& E. Hidayah. 2013. Pengaruh Environmental Performance dan Environmental Disclosure terhadap Economic Performance. EKBISI. Vol. 7, No. 2, hal. 233-244.

Yendrawati, R. \& L. R. Tarusnawati. 2013. Peran Environmental Performance Terhadap Environmental Disclosure dan Economic Performance. Jurnal Keuangan dan Perbankan, Vol. 17, No. 3, hal. 434-442.

Zuhroh, D. \& I P. P. H. Sukmawati. 2003. Analisis Pengaruh Luas Pengungkapan Sosial dalam Laporan Tahunan Perusahaan terhadap Reaksi Investor. Simposium Nasional Akuntansi VI. Surabaya. 